\title{
Cardiopulmonary function studies in workers dealing with asbestos and glasswool ${ }^{\prime}$
}

\author{
J. B J U R E, B. SÖ D E R H O L M, A N D J . W I D I M S K Y 23 \\ From the Department of Clinical Physiology, Sahlgrenska Sjukhuset, \\ University of Göteborg, Göteborg, Sweden
}

Pulmonary fibrosis is thought to be a common complication of exposure to asbestos dust. The inhaled asbestos fibres are supposedly not transported by the pulmonary lymphatics, and thus one single massive exposure might lead to the same stage of fibrosis as a prolonged but less intense exposure.

This industrial hazard has led to the search for substitutes for asbestos in insulation work, and at present glasswool and rockwool are often used. The fragmentation of these materials may give rise to fibre particles which can be inhaled and deposited in the alveoli. The possible effect on cardiopulmonary function in a group of men doing insulation work, with prolonged exposure to glasswool and rockwool dust, is the subject of the present paper, and a similarly exposed group of asbestos workers was studied for comparison.

\section{MATERIAL}

These men have regular routine medical examinations. All the subjects in this study, which formed part of a general survey, were gainfully employed male insulators who volunteered. Their employment records were carefully studied in an effort to evaluate the kind of dust to which they had been exposed. Group A consisted of eight subjects whose exposure to asbestos dust comprised at least $50 \%$ of their employment time. In all subjects the chest radiographs suggested asbestosis, and two patients complained of cough and exertional dyspnoea. Six subjects were selected who had had prolonged exposure to glasswool and rockwool but only minimal exposure to asbestos dust (group B). They had no history of cardiopulmonary disease. Physical findings and chest radiographs were considered normal.

Clinical, radiological, and occupational data are recorded in Table I.

\footnotetext{
I Supported by a grant from Statens Medicinska Forskningsräd 2 Research fellow of Svenska Nationalföreningen mot hjäroch lungsjukdomar

3 Present address: Institute for Cardiovascular Diseases, PrahaKrě. Budéjovická 800, Czechoslovakia
}

\section{METHODS}

Dynamic spirometry was performed, as described by Berglund, Birath, Bjure, Grimby, Kjellmer, Sandqvist, and Söderholm (1963).

Functional residual capacity (F.R.C.) was determined in the supine position, using an open-circuit nitrogen wash-out technique (Lundin and Åkesson, 1954). The volume required to wash out the nitrogen from 1 litre F.R.C. to an end-tidal concentration of $2 \%$, lung clearance index (L.C.I.), was calculated from these records (Becklake, 1952).

Electrocardiography was performed using five chest electrodes (CR) and the conventional limb leads as well as aVR, aVL, and aVF. Physical performance was studied on a bicycle ergometer as described by Sjöstrand (1947). The heaviest work load which could be maintained in a steady state, as judged from the heart rate, was used as an index of the physical performance (Grimby and Söderholm, 1963).

Heart catheterization was performed in the morning after a light meal. A double-lumen catheter (no. 9) was wedged in a pulmonary artery (P.C.V. position) with the proximal lumen in the pulmonary artery. Brachial artery pressure was recorded from an indwelling polythene tube. Pressures were recorded with strain-gauge manometers on a six-channel directwriting recorder. ${ }^{4}$ A point $5 \mathrm{~cm}$. dorsal to the sternal angle was used as zero reference level. Mean pressures were measured by electrical integration. Cardiac output was estimated according to Fick's direct principle.

Gas analyses and measurements of oxygen saturation and oxygen capacity were performed as described by Holmgren and Pernow (1959). The oxygen tension in arterial blood was determined by the potentiometric method described by Gleichmann and Lübbers (1960). The alveolo-arterial difference in oxygen tension was calculated from the alveolar air equation and the arterial oxygen tension. Venous admixture to arterial blood was calculated in per cent of cardiac output, assuming an end-capillary oxygen saturation of $98 \%$.

After introduction of the catheters the subjects were allowed to rest for 30 minutes. Pressures and flows were then studied in the supine position. All measure-

\footnotetext{
4 Mingograph, Elema
} 
TABLE I

\begin{tabular}{|c|c|c|c|c|c|c|c|c|c|}
\hline $\begin{array}{l}\text { Sub- } \\
\text { ject } \\
\text { No. }\end{array}$ & Age & $\begin{array}{l}\text { Height } \\
\text { (cm.) }\end{array}$ & $\begin{array}{l}\text { Pleural } \\
\text { Thick- } \\
\text { ening }\end{array}$ & $\begin{array}{l}\text { Streak- } \\
\text { ing } \\
\text { Mottling }\end{array}$ & $\begin{array}{c}\text { Dysp- } \\
\text { noea }\end{array}$ & $\begin{array}{c}\text { Working } \\
\text { Capacity } \\
\text { (kpm./min.) }\end{array}$ & $\begin{array}{l}\text { Pulse } \\
\text { Rate }\end{array}$ & $\begin{array}{c}\text { Res- } \\
\text { piratory } \\
\text { Rate }\end{array}$ & Occupational History \\
\hline 1 & 29 & 167 & $\dot{-}$ & - & - & 600 & 124 & 30 & 11 yr. almost exclusively rockwool and glasswool; \\
\hline 2 & 37 & 191 & - & - & - & 1,200 & 157 & 30 & 22 yr. exclusively rockwool and glasswool; no exposure \\
\hline 3 & 41 & 171 & - & - & - & 600 & 128 & 20 & 25 yr. almost exclusively rockwool and glasswool; \\
\hline $\begin{array}{l}4 \\
5\end{array}$ & $\begin{array}{l}37 \\
45\end{array}$ & $\begin{array}{l}177 \\
187\end{array}$ & - & - & - & $\begin{array}{r}900 \\
1,200\end{array}$ & $\begin{array}{l}160 \\
162\end{array}$ & $\begin{array}{l}28 \\
28\end{array}$ & $\begin{array}{l}8 \text { yr. exclusively rockwool and glasswool } \\
29 \text { yr. Since } 15 \text { yr. no exposure to asbestos but has earlier }\end{array}$ \\
\hline 6 & 45 & 178 & - & - & - & 900 & 172 & 28 & $\begin{array}{l}11 \text { yr. almost exclusively rockwool and glass wool; } \\
\text { minimal exposure to asbestos }\end{array}$ \\
\hline $\begin{array}{c}71 \\
8 \\
9 \\
10 \\
11 \\
12 \\
13 \\
14\end{array}$ & $\begin{array}{l}48 \\
50 \\
40 \\
33 \\
51 \\
49 \\
47 \\
46\end{array}$ & $\begin{array}{l}180 \\
168 \\
188 \\
173 \\
172 \\
168 \\
168 \\
164\end{array}$ & $\begin{array}{l}+2 \\
+2 \\
+ \\
+ \\
+2 \\
+ \\
+2 \\
+\end{array}$ & $\begin{array}{l}+ \\
+ \\
+ \\
+ \\
+ \\
+ \\
+\end{array}$ & $\begin{array}{l}\overrightarrow{+} \\
\overline{-} \\
\overline{-} \\
\pm\end{array}$ & $\begin{array}{r}900 \\
900 \\
600 \\
1,200 \\
900 \\
900 \\
600 \\
600\end{array}$ & $\begin{array}{l}154 \\
152 \\
120 \\
180 \\
165 \\
165 \\
130 \\
115\end{array}$ & $\begin{array}{l}36 \\
40 \\
28 \\
44 \\
28 \\
30 \\
36 \\
28\end{array}$ & $\begin{array}{l}30 \mathrm{yr} \text {. exposure to both asbestos and rockwool } \\
25 \mathrm{yr} \text {. exposure to both asbestos and rockwool } \\
10 \mathrm{yr} \text {. mostly exposure to asbestos but has used face mask } \\
11 \mathrm{yr} \text {. mostly exposure to asbestos but has used face mask } \\
30 \mathrm{yr} \text {. mostly exposure to asbestos } \\
22 \mathrm{yr} \text {. mostly exposure to asbestos } \\
7 \mathrm{yr} \text {. mostly exposure to asbestos } \\
9 \mathrm{yr} \text {. mostly exposure to asbestos (mattresses) }\end{array}$ \\
\hline
\end{tabular}

1 Scoliosis of thoracic spine. 2 Pleural and/or diaphragmatic calcifications.

TPA B LE II

PULMONARY FUNCTION STUDIES

\begin{tabular}{|c|c|c|c|c|c|c|c|c|c|c|}
\hline \multirow{2}{*}{$\begin{array}{c}\text { Subject } \\
\text { No. }\end{array}$} & \multicolumn{2}{|c|}{ V.C. (1.) } & \multicolumn{2}{|c|}{ F.E. $V_{\cdot 1 \cdot 0}(1)}$. & \multicolumn{2}{|c|}{ F.E.V. $\%$} & \multirow{2}{*}{$\underset{\text { Difference }}{\mathbf{N}_{2}}$} & \multirow{2}{*}{ F.R.C. } & \multirow{2}{*}{ L.C.I. } & \multirow{2}{*}{$\mathbf{D}_{\mathbf{L}_{\text {co }}}$} \\
\hline & Found & Predicted & Found & Predicted & Found & Predicted & & & & \\
\hline $\begin{array}{c}\text { Group } \\
1 \\
2 \\
3 \\
4 \\
5 \\
6\end{array}$ & $\begin{array}{l}4 \cdot 68 \\
5 \cdot 76 \\
4 \cdot 55 \\
4 \cdot 86 \\
4 \cdot 76 \\
4 \cdot 52\end{array}$ & $\begin{array}{l}4 \cdot 67 \\
5.64 \\
4.55 \\
4.97 \\
5 \cdot 29 \\
4.88\end{array}$ & $\begin{array}{l}3.96 \\
3.83 \\
3.44 \\
2.92 \\
3.39 \\
3.44\end{array}$ & $\begin{array}{l}3 \cdot 84 \\
4 \cdot 37 \\
3 \cdot 51 \\
3 \cdot 88 \\
3.97 \\
3.69\end{array}$ & $\begin{array}{l}85 \\
66 \\
76 \\
60 \\
71 \\
76\end{array}$ & $\begin{array}{l}81 \\
78 \\
77 \\
78 \\
75 \\
76\end{array}$ & $\begin{array}{l}0.9 \\
1.8 \\
0.9 \\
2.1 \\
2.5 \\
1.4\end{array}$ & $\begin{array}{l}3.02 \\
1.76 \\
1.98 \\
2.59 \\
2.44\end{array}$ & $\begin{array}{l}-\overline{9 \cdot 0} \\
7 \cdot 8 \\
6 \cdot 3 \\
9 \cdot 0 \\
7 \cdot 8\end{array}$ & $\begin{array}{l}19 \cdot 6 \\
30 \cdot 1 \\
21 \cdot 7 \\
20 \cdot 2 \\
29 \cdot 4 \\
22 \cdot 2\end{array}$ \\
\hline $\begin{array}{c}\text { Group } A \\
7 \\
8 \\
9 \\
10 \\
11 \\
12 \\
13 \\
14\end{array}$ & $\begin{array}{l}4 \cdot 42 \\
2.69 \\
4.03 \\
3.08 \\
3.83 \\
3.36 \\
3.44 \\
2.90\end{array}$ & $\begin{array}{l}4 \cdot 89 \\
4 \cdot 27 \\
5 \cdot 44 \\
4 \cdot 84 \\
4 \cdot 43 \\
4 \cdot 29 \\
4 \cdot 31 \\
4 \cdot 16\end{array}$ & $\begin{array}{l}2.92 \\
1.96 \\
3 \cdot 31 \\
2 \cdot 69 \\
2 \cdot 22 \\
2.64 \\
2.97 \\
2 \cdot 30\end{array}$ & $\begin{array}{l}3 \cdot 63 \\
3 \cdot 14 \\
4 \cdot 17 \\
3 \cdot 84 \\
3 \cdot 22 \\
3 \cdot 18 \\
3 \cdot 21 \\
3 \cdot 14\end{array}$ & $\begin{array}{l}66 \\
73 \\
82 \\
87 \\
58 \\
78 \\
86 \\
79\end{array}$ & $\begin{array}{l}74 \\
73 \\
77 \\
79 \\
73 \\
74 \\
74 \\
75\end{array}$ & $\begin{array}{l}1 \cdot 8 \\
6 \cdot 5 \\
0 \cdot 9 \\
5 \cdot 4 \\
0.8 \\
1 \cdot 5 \\
6 \cdot 3\end{array}$ & $\begin{array}{l}2.36 \\
3.31 \\
1.89 \\
3.07 \\
2.76 \\
1.88 \\
2.05\end{array}$ & $\begin{array}{c}10.6 \\
8.3 \\
10.2 \\
11 \cdot 8 \\
7.0 \\
11 \cdot 3 \\
8.8\end{array}$ & $\begin{array}{r}9.4 \\
15.2 \\
17 \cdot 3 \\
21.2 \\
11.8 \\
15.0 \\
11.5 \\
11.9\end{array}$ \\
\hline $\begin{array}{c}\text { Mean values } \\
\text { Group B } \\
\text { Group A }\end{array}$ & $\begin{array}{l}4 \cdot 86 \\
3 \cdot 47\end{array}$ & $\begin{array}{c}101 \% \\
76 \%\end{array}$ & $\begin{array}{l}3 \cdot 50 \\
2 \cdot 63\end{array}$ & $\begin{array}{l}90 \% \\
76 \%\end{array}$ & $\begin{array}{l}72 \\
76\end{array}$ & $\begin{array}{l}78 \\
75\end{array}$ & $\begin{array}{l}1 \cdot 6 \\
3 \cdot 3\end{array}$ & $\begin{array}{l}2 \cdot 36 \\
2 \cdot 48\end{array}$ & $\begin{array}{l}7 \cdot 06 \\
9 \cdot 71\end{array}$ & $\begin{array}{l}23 \cdot 9 \\
14 \cdot 2\end{array}$ \\
\hline $\begin{array}{c}\text { P-values for } \\
\text { difference } \\
\text { A-B } \quad \ldots\end{array}$ & $<0.01$ & & $<0.01$ & & $>0.05$ & & $>0.05$ & $>0.05$ & $>0.05$ & $<0.01$ \\
\hline
\end{tabular}

V.C. = vital capacity (1. A.T.P.S.) sitting. F.E.V. $\cdot_{1 \cdot 0}=$ forced expired volume in 1 sec. (1. A.T.P.S.) sitting. F.E.V. $\%=$ forced expired volume in 1 sec. in per cent of vital capacity. $N_{2}$ difference ='single breath' difference in expired $N_{2}$ content between 750 and 1,250 ml. F.R.C. $=$ functional residual capacity (1. B.T.P.S.) supine. L.C.I. =lung clearance index (litres of total ventilation per litre of $F . R . C$.). $D_{1} c_{0}=$ pulmonary diffusing capacity for carbon monoxide ( $\mathrm{ml} . / \mathrm{min} . \times \mathrm{mm}$. Hg).

ments were made under steady-state conditions, as judged by pulse rate and pressures. Haemodynamic data were studied during rest only in group $B$ and during rest and exercise in group $\mathbf{A}$.

The diffusing capacity of the lung was determined at rest using the steady-state carbon monoxide method described by Filley, MacIntosh, and Wright (1954), modified according to Linderholm (1957). Carbon monoxide was analysed in a hopcalite apparatus (Stålex). The carbon monoxide content of arterial blood was determined after release of $\mathrm{CO}$ by sulphuric acid in an extraction chamber. 
impaired distribution of the inspired air, as judged from the lung clearance index and single-breath $\mathrm{N}_{2}$ test.

Physical performance (Table I) was comparable in the two groups. In only one subject (no. 13) in group $\mathbf{A}$ was there any reason to suspect a limitation of the working capacity because of impaired ventilation. However, all subjects in group A had a tendency to use a higher respiratory rate at a given work load than the subjects in group B.

Table III shows the haemodynamic data. Also from this table it is evident that the abnormal findings are confined to group A. Even though the average pulmonary artery pressure is not definitely raised for the whole group, the difference between groups is significant, as is the difference in calculated pulmonary vascular resistance.

The respiratory data are given in Table IV. When comparing the two groups there is a significant difference only in the arterial oxygen tension and the alveolo-arterial oxygen tension difference. However, the lowest oxygen saturations, as well as the highest $V_{D} / V_{T}$ and $Q_{s} / Q_{t}$, are found in group $\mathrm{A}$.
In both groups some subjects (nos. 4, 6, 7, and 12) had a low arterial $\mathrm{PCO}_{2}$ at rest. This has been interpreted as being due to anxiety. The normal value during exercise in subject 12 gives some support to this interpretation.

In subject 8 essential hypertension might be suspected because of the increased brachial artery pressure and systemic vascular resistance.

Electrocardiography revealed in group B only one subject with signs suggestive of right ventricular hypertrophy (R.V.H.) but here the pulmonary artery (P.A.) pressure was normal. In group A two subjects had the E.C.G. pattern of R.V.H. ; one had a normal P.A. pressure at rest whereas the other had pathologically raised pressures both at rest and on exercise. Three other subjects had signs suggestive only of R.V.H. Of these only one had an abnormally raised P.A. pressure at work. One subject with pulmonary hypertension at rest had a normal E.C.G.

In view of the difference between the two groups these findings indicate that electrocardiographic signs of right ventricular hypertrophy in a subject exposed to asbestos dust would indicate the necessity for further cardiopulmonary function studies.

TABLE III

HAEMODYNAMIC DATA

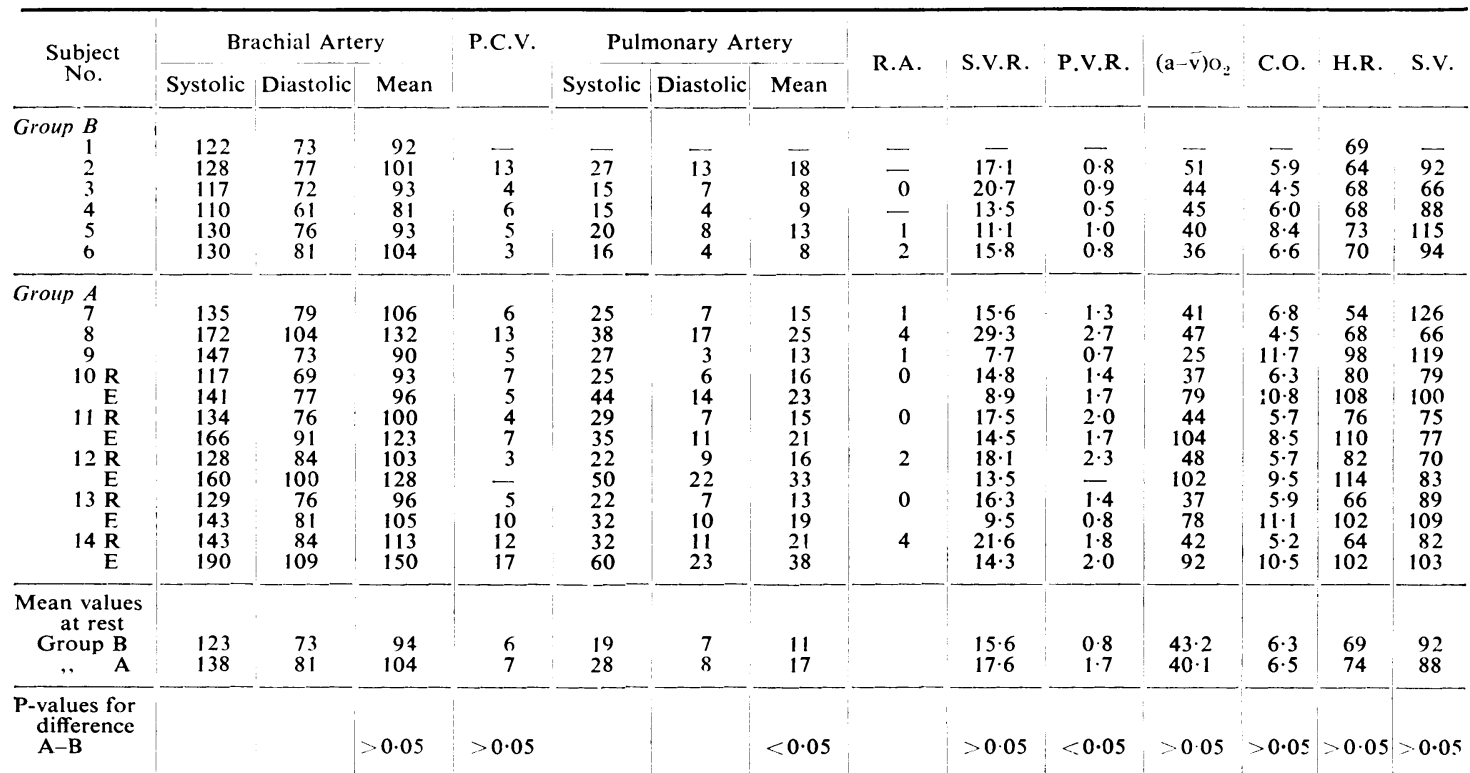

All pressures are given in mm. Hg. P.C.V. = pulmonary artery wedge pressure. R.A. = right atrium pressure. S.V.R. =- systemic vascular resistance

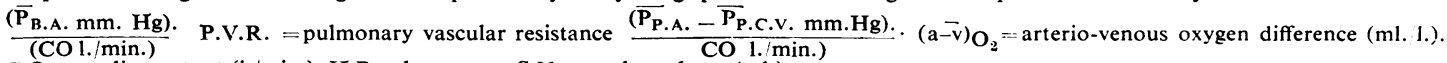
C.O. = cardiac output (1. min.). H.R. := heart rate. S.V. = stroke volume (ml.). 
TABLE IV

RESPIRATORY DATA

\begin{tabular}{|c|c|c|c|c|c|c|c|c|c|}
\hline Subject No. & $\mathrm{s}_{\mathrm{a}_{\mathrm{O}_{2}}}$ & $\mathrm{O}_{2}$-cap. & $\dot{\mathrm{v}}_{\mathrm{O}_{2}}$ & $\dot{\mathbf{v}}_{\mathbf{E}}$ & $\mathbf{V}_{\mathbf{D}} / \mathbf{V}_{\mathbf{T}}$ & $\mathrm{Pa}_{\mathrm{CO}_{2}}$ & $\mathrm{P}_{\mathrm{a}_{\mathbf{O}_{\mathbf{3}}}}$ & $(A-a) O_{2}$ & $\mathrm{Q}_{\mathbf{s}} / \mathbf{Q}_{\mathbf{A}}$ \\
\hline $\begin{array}{rr}\text { Group } & B \\
1 \\
2 \\
3 \\
3 \\
4 \\
5 \\
6\end{array}$ & $\begin{array}{l}97 \\
97 \\
97 \\
98 \\
96 \\
98\end{array}$ & $\begin{array}{l}17.8 \\
19.8 \\
18.7 \\
17.5 \\
18.5 \\
18.2\end{array}$ & $\begin{array}{l}240 \\
300 \\
199 \\
270 \\
334 \\
239\end{array}$ & $\begin{array}{r}6.8 \\
7.9 \\
6 \cdot 4 \\
14.3 \\
10.1 \\
8 \cdot 0\end{array}$ & $\begin{array}{l}35 \\
33 \\
25 \\
32 \\
32 \\
27\end{array}$ & $\begin{array}{l}40 \\
39 \\
32 \\
24 \\
36 \\
30\end{array}$ & $\begin{array}{r}96 \\
99 \\
99 \\
121 \\
86 \\
108\end{array}$ & $\begin{array}{r}8 \\
4 \\
16 \\
5 \\
23 \\
6\end{array}$ & $\begin{array}{l}5 \cdot 8^{1} \\
5 \cdot 2 \\
5 \cdot 6 \\
0 \\
8 \cdot 5 \\
2 \cdot 5\end{array}$ \\
\hline $\begin{array}{rr}\text { Group } A \\
7 \\
8 \\
8 \\
9 \\
10 \mathrm{R} \\
\mathrm{R} \\
11 \mathrm{E} \\
\mathrm{E} \\
\mathrm{E} \\
12 \mathrm{E} \\
\mathrm{R} \\
13 \mathrm{E} \\
13 \mathrm{R} \\
\mathrm{E} \\
14 \mathrm{R} \\
\mathrm{E}\end{array}$ & $\begin{array}{l}98 \\
98 \\
97 \\
96 \\
26 \\
92 \\
94 \\
97 \\
97 \\
93 \\
94 \\
96 \\
96\end{array}$ & $\begin{array}{l}17.3 \\
19.4 \\
17.6 \\
17.7 \\
18.8 \\
19.8 \\
19.9 \\
20.2 \\
19.5 \\
17.2 \\
17.6 \\
18.1 \\
19.8\end{array}$ & $\begin{array}{l}278 \\
215 \\
293 \\
243 \\
852 \\
252 \\
880 \\
272 \\
971 \\
219 \\
867 \\
220 \\
964\end{array}$ & $\begin{array}{r}11.7 \\
6.9 \\
99.0 \\
79.5 \\
19.1 \\
99.5 \\
25.1 \\
13.1 \\
22.9 \\
6.5 \\
25.8 \\
7.7 \\
31.4\end{array}$ & $\begin{array}{l}34 \\
27 \\
46 \\
15 \\
22 \\
43 \\
21 \\
23 \\
18 \\
31 \\
27 \\
40 \\
24\end{array}$ & $\begin{array}{l}30 \\
35 \\
39 \\
41 \\
42 \\
36 \\
36 \\
19 \\
37 \\
34 \\
36 \\
35 \\
33\end{array}$ & $\begin{array}{r}91 \\
85 \\
79 \\
88 \\
92 \\
72 \\
89 \\
104 \\
83 \\
83 \\
83 \\
82 \\
79\end{array}$ & $\begin{array}{c}27 \\
27 \\
19 \\
(9) \\
(90) \\
35 \\
20 \\
20 \\
21 \\
22 \\
24 \\
26 \\
34\end{array}$ & $\begin{array}{r}0 \\
1.2 \\
6.6 \\
77.5 \\
4.5 \\
21.3 \\
6.6 \\
2.9 \\
2.4 \\
19.2 \\
7.5 \\
6.8 \\
4.7\end{array}$ \\
\hline $\begin{array}{c}\text { Mean values } \\
\text { at rest } \\
\text { Group B } \\
, \| \quad \text { A }\end{array}$ & $\begin{array}{l}97.0 \\
95.9\end{array}$ & $\begin{array}{l}18.4 \\
18.4\end{array}$ & $\begin{array}{l}264 \\
249\end{array}$ & $\begin{array}{l}8.9 \\
9 \cdot 0\end{array}$ & $\begin{array}{l}30 \cdot 7 \\
36 \cdot 1\end{array}$ & $\begin{array}{l}33.5 \\
33.6\end{array}$ & $\begin{array}{r}101.5 \\
85.5\end{array}$ & $\begin{array}{l}10 \cdot 3 \\
23 \cdot 1\end{array}$ & $\begin{array}{l}4 \cdot 6 \\
8 \cdot 2\end{array}$ \\
\hline $\begin{array}{l}\text { P-values for } \\
\text { difference } \\
\text { A-B }\end{array}$ & $>005$ & $>0.05$ & $>0.05$ & $>0.05$ & $>0.05$ & $>0.05$ & $<0.02$ & $<C \cdot 01$ & $>0.05$ \\
\hline
\end{tabular}

${ }_{1}^{1}(\mathrm{a}-\overrightarrow{\mathrm{v}})_{\mathrm{O}_{2}}$ difference assumed to be $4 \cdot 30$ vol.\%. Figures in parentheses indicate $\mathrm{P}_{\mathrm{a}_{2}}$ calculated from Dill curve.

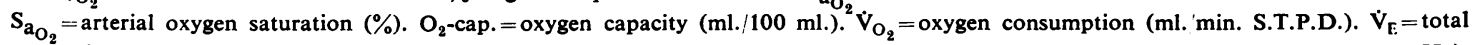
ventilation (1./min. B.T.P.S.). $\mathrm{V}_{\mathrm{D}} / \mathrm{V}_{\mathrm{T}}=$ dead space veittilation in per cent of total ventilation. $\mathrm{P}_{\mathrm{a}_{\mathrm{CO}}}=$ arterial carbon dioxide tension (mm. $\mathrm{Hg}$ ). $(A-a))_{O_{2}}=$ alveolo-arterial oxygen tension difference $(\mathrm{mm} . \mathrm{Hg}) \cdot \mathrm{P}_{\mathrm{a}_{\mathrm{O}_{2}}}=$ arterial oxygen tension $(\mathrm{mm}$. $\mathrm{Hg}) . \mathrm{Q}_{\mathrm{s}} / \mathrm{Q}_{\mathrm{i}}=$ venous admixture in per cent of cardiac output.

\section{DISCUSSION}

The subjects studied were selected from a larger group of insulation workers. They all had similar working conditions and employment times, the main difference being the insulating material used. A positive diagnosis of asbestosis was made in the presence of prolonged exposure to asbestos dust or radiological findings suggestive of asbestosis.

To exclude any exposure to asbestos dust in the group of glasswool workers proved impossible. However, the time of exposure to asbestos was much shorter, and no one had been employed in the production of mattresses etc., where the exposure to dust is known to be severe. The absence of radiological findings was considered confirmative. Nevertheless any patho-physiological findings in group B should be judged with caution since asbestosis might occur even without radiological changes (Williams and Hugh-Jones, 1960 ; Leathart, 1960). In spite of prolonged exposure to glasswool and rockwool dust no subjects in group B have shown impairment of those cardiopulmonary functions studied. Thus it seems safe to conclude that prolonged exposure to this type of dust does not initiate any fibrosis of the lungs.
This is in agreement with studies performed on different animal species by Schepers, Durkan, Delahant, Redlin, Schmidt, Creedon, Jacobson, and Bailey (1958) and by Schepers (1959). They found an essentially cellular reaction to glasswool particles while the deposition of collagen in the lungs is very slight compared to that in asbestosis. The main patho-anatomical findings have been peribronchiolar and perivascular infiltrations sometimes combined with proliferative cell masses obliterating the alveolar lumen. No signs of fibrosis have been observed and all the changes described have been reversible on cessation of exposure.

There are few patho-anatomical studies performed on human lungs, but Kahlau (1947) reports on a patient who died with pneumonia after a relatively short period of exposure to glasswool. Microscopy revealed foreign bodies, supposedly glasswool particles, but no fibrotic reaction. Murphy (1961) describes multiple focal abscesses arising from terminal bronchi and bronchioles containing glass fibres and only slight fibrosis.

Patho-anatomical studies of the lungs in cases of asbestosis have shown dense fibrosis of the 
pleura, often with calcifications and a more or less generalized fibrosis of the lung parenchyma (Vorwald, Durkan, and Pratt, 1951 ; Heard and Williams, 1961). These patho-anatomical findings should be compared with the physiological alterations observed.

There are several findings in asbestosis which have been attributed to the induced fibrosis.

DECREASED VITAL CAPACITY This is a common finding (Leathart, 1960; Bastenier, Denolin, de Coster, and Englert, 1955; Williams and HughJones, 1960) and in our subjects the V.C. averaged $76 \%$ of predicted normal. There was a poor correlation between the radiological findings and a decrease in V.C. Calcifications were found both in cases with a markedly reduced and an almost normal V.C. On the other hand, those subjects with the lowest V.C. also had an elevated pulmonary artery pressure at rest or during exercise. Similar observations have been made by Söderholm (1957) in patients with pulmonary tuberculosis where a good correlation was found between a reduced maximum voluntary ventilation and increased pulmonary artery pressure during standardized exercise. This observation might be of importance as a simple screening test.

LOW COMPLIANCE OF THE LUNG Leathart (1960) found a markedly reduced dynamic compliance which was closely correlated to the reduction in vital capacity. Similar findings have been reported by Rubino, Garbagni, Scansetti, and Carelli (1961).

DECREASED PULMONARY DIFFUSING CAPACITY This has been found by several authors (Leathart, 1960 ; Williams and Hugh-Jones, 1960 ; Thomson, McGrath, Smither, and Shepherd, 1961).

In our group A six of eight subjects had both a reduced diffusing capacity and an increased pulmonary vascular resistance (Fig. 1). Such an increased vascular resistance in the absence of any indications of obstructive lung disease fits well with the concept of a reduced pulmonary vascular bed due to pulmonary fibrosis. There is no direct relation between vascular resistance and diffusing capacity even if an increased resistance is usually found in cases with a reduced diffusing capacity. Thus the impairment of diffusing capacity might be due to both a reduction in the pulmonary capillary bed and alterations in the alveolar membrane and/or uneven distribution of the diffusion to perfusion ratios. Measurement of the end-capillary oxygen tension is not possible, but some deductions can be made since the mean

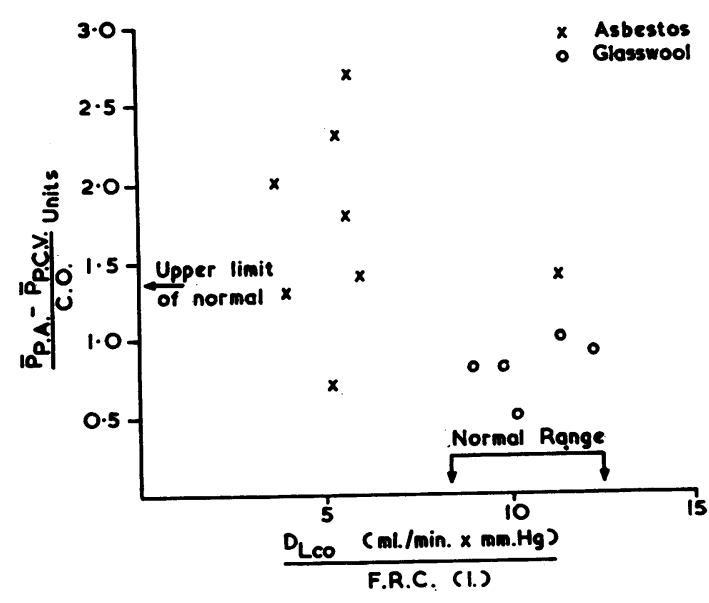

FIG. 1. Pulmonary diffusing capacity per litre functional residual capacity $\left(D L_{\text {co }} /\right.$ l. F.R.C.) in comparison with the pulmonary vascular resistance (P.V.R.) at rest. The normal limits are derived from subjects studied with the same techniques in this laboratory: $D L_{\text {co }} /$ l. F.R.C.: 12 subjects 20-25 years of age. P.V.R.: 12 subjects 21-50 years of age.

diffusion gradient for oxygen is readily calculated from the $\mathrm{DL}_{\mathrm{co}}$. In the two groups the average mean diffusion gradient was $15 \mathrm{~mm}$. $\mathrm{Hg}$ in group $A$ and $9 \mathrm{~mm}$. $\mathrm{Hg}$ in group $\mathrm{B}$, when the total alveolo-arterial $\mathrm{O}_{2}$ difference was 23 and $10 \mathrm{~mm}$. $\mathrm{Hg}$, respectively. As the average arterial $\mathrm{O}_{2}$ tension was 86 and $102 \mathrm{~mm}$. $\mathrm{Hg}$ in the two groups, the end-capillary oxygen tension must have exceeded $95 \mathrm{~mm}$. Hg. It is thus reasonable to assume an end-capillary oxygen saturation of $98 \%$ and an end-capillary $\mathrm{O}_{2}$ gradient of less than $5 \mathrm{~mm}$. $\mathrm{Hg}$. The contribution of venous admixture to the over-all alveolo-arterial oxygen difference approximates 5 and $18 \mathrm{~mm}$. $\mathrm{Hg}$ in groups $\mathrm{B}$ and $\mathrm{A}$ respectively. These figures agree closely with the $Q_{s} / Q_{t}$ of $5 \%$ and $8 \%$ calculated otherwise. It is a matter of conjecture whether this admixture of poorly oxygenated blood is considered a result of perfusion of poorly ventilated alveoli or the interposition of an enormously thickened alveolar wall between normally ventilated and perfused alveoli ( $c f$. ., Piiper, 1961). When calculating the effect of increasing alveolo-capillary membrane thickness on the $\mathrm{O}_{2}$ diffusing capacity, Finley, Swenson, and Comroe (1962) found that a six- to eight-fold increase of the membrane must occur before the alveolo-arterial $\mathrm{O}_{2}$ tension difference is measurable $(1 \mathrm{~mm}$. $\mathrm{Hg})$. Thus uneven distribution of ventilation in relation to blood flow is a more probable cause of hypoxaemia even in cases with advanced impairment of diffusion. 
Thus our data indicate a mixed impairment of the gas transport mechanisms where both an impaired diffusion and a disturbance of the ventilation-perfusion ratio coexist. This is in agreement with the observations of Williams and Hugh-Jones (1960) and of Bader, Bader, and Selikoff (1961).

No relation was found between physical performance or radiological findings and diffusing capacity. This might indicate that an impaired diffusing capacity is a sensitive index of asbestosis, which Williams and Hugh-Jones have already stated. Leathart showed that among asbestos workers those with radiological changes had a significantly lower diffusing capacity.

In three of eight subjects a pathologically increased pulmonary artery pressure at rest and/or during light exercise was found. Bearing in mind that all subjects were gainfully employed and symptom-free and that the investigation was performed as part of a routine health check up, this is a surprisingly high incidence. Presumably they represent moderately advanced cases of asbestosis and yet their cardiopulmonary function studies have shown marked deviations from normal.

These findings put further emphasis on the importance of preventive medical supervision of workers exposed to asbestos dust.

It is concluded that even prolonged exposure to glasswool and rockwool does not cause any significant impairment of cardiopulmonary function. On the other hand, similar exposure to asbestos does cause such impairment even if the subjects are symptom-free and fit for work.

\section{SUMMARY}

Cardiopulmonary function studies have been performed in insulators exposed to glasswool or asbestos.

With a similar time of exposure glasswool did not cause any detectable functional impairment. Exposure to asbestos gave rise to a marked restriction in dynamic lung function, a reduced diffusing capacity, and, in three out of eight subjects, a pathologically raised pulmonary artery pressure at rest or during exercise.
We would like to thank Dr. G. Ahlborg without whose help much of this study would have been impossible. We are indebted to Dr. L.-O. Lanner for an interpretation of the chest radiographs.

\section{REFERENCES}

Bader, M. E., Bader, R. A., and Selikoff, I. J. (1961). Pulmonary function in asbestosis of the lung, an alveolar-capillary block syndrome. Amer.J. Med., 30, 235.

Bastenier, H., Denolin, H., de Coster, A., and Englert, M. (1955). Etude de la fonction respiratoire dans l'asbestose pulmonaire. Arch. Mal. prof., 16, 546.

Becklake, M. R. (1952). A new index of the intrapulmonary mixture of inspired air. Thorax, $7,111$.

Berglund, E., Birath, G., Bjure, J., Grimby, G., Kjellmer, I., Sandqvist, L., and Söderholm, B. (1963). Spirometric studies in normal subjects. I. Forced expirograms in subjects between 7 and 70 years of age. Acta med. scand., 173, 185 .

Filley, G. F., MacIntosh, D. J., and Wright, G. W. (1954). Carbon monoxide uptake and pulmonary diffusing capacity in normal subjects at rest and during exercise. J. clin. Invest., 33, 530 .

Finley, T. N., Swenson, E. W., and Comroe, J. H. (1962). The cause of arterial hypoxemia at rest in patients with 'alveolar-capillary block syndrome'. Ibid., 41, 618 .

Gleichmann, U., and Lübbers, D. W. (1960). Die Messung des Sauerstoffdruckes in Gasen und Flüssigkeiten mit der Pt-Elektrode unter besonderer Berücksichtigung der Messung im Blut Pflügers Arch. ges. Physiol.. 271. 431.

Grimby, G., and Söderholm, B. (1963). Spirometric studies in normal subjects. III. Static lung volumes and maximum voluntary. ventilation in adults with a note on physical fitness. Acta med. scand., 173, 199.

Heard, B. E., and Williams, R. (1961). The pathology of asbestosis with reference to lung function. Thorax, 16, 264.

Holmgren, A., and Pernow, B. (1959). Spectrophotometric measurement of oxygen saturation of blood in the determination of cardiac output. A comparison with the Van Slyke method. Scand. J. clin. Lab. Invest., 11, 143.

Kahlau, G. (1947). Tödliche Pneumonie nach Glasstaubinhalation durch Verarbeitung eines Kunststoffes aus Glaswolle. Frankfurt. Z. Path., $59,143$.

Leathart, G. L. (1960). Clinical, bronchographic, radiological and physiological observations in ten cases of asbestosis. Brit. $J$. industr. Med., 17, 213.

Linderholm, H.(1957). On the significance of CO tension in pulmonary capillary blood for determination of pulmonary diffusing capacity with the steady state CO method. Acta med. scand., 156, 413 .

Lundin, G., and Akesson, L. (1954). A new nitrogen meter model. Scand. J. clin. Lab. Invest., 6, 250.

Murphy,G. B., Jr. (1961). Fiber glass pneumoconiosis. Arch. environm. Hlth, $\mathbf{3}, \mathbf{7}$ 4.

Piiper, J. (1961). Variations of ventilation and diffusing capacity to perfusion determining the alveolar-arterial $\mathrm{O}_{2}$ difference : theory. J. appl. Physiol., 16, 507.

Rubino, G. F., Garbagni, R., Scansetti, G., and Carelli, E. (1961). Aspetti di fisiopatologia respiratoria e circolatoria nell'asbestosi polmonare. Med. $d$. Lavoro, 52, 515.

Schepers, G. W. H. (1959). Pulmonary histologic reactions to inhaled fiberglass plastic dust. Amer. J. Path., 35, 1169.

- Durkan, T. M., Delahant, A. B., Redlin, A. J., Schmidt, J. G., Creedon, F. T., Jacobson, J. W., and Bailey, D. A. (1958). The biological action of fiberglas-plastic dust. A.M.A. Arch. industr. Hlth, 18, 34.

Sjöstrand, T. (1947). Changes in the respiratory organs of workmen at an ore smelting works. Acta med. scand., Suppl. 196, p. 687.

Söderholm, B. (1957). The hemodynamics of the lesser circulation in pulmonary tuberculosis. Scand. J. clin. Lab. Invest., 9, suppl. 26.

Thomson, M. L., McGrath, M. W. Smither, W. J., and Shepherd, J. M. (1961). Some anomalies in the measurement of pulmonary diffusion in asbestosis and chronic bronchitis with emphysema. Clin. Sci., 21, 1.

Vorwald, A. J., Durkan, T. M., and Pratt, P. C. (1951). Experimental studies of asbestosis. A.M.A. Arch. industr. Hyg., 3, 1.

Williams, R., and Hugh-Jones, $\mathbf{P}$. (1960). The significance of lung function changes in asbestosis. Thorax, 15, 109. 